\title{
Choking BioShield: The Department of Homeland Security's Stranglehold on Biodefense Vaccine Development
}

\author{
Michael Greenberger ${ }^{1}$
}

December 20, 2005

One of the bright milestones toward the development of a vibrant biodefense vaccine industry was the passage of the Project BioShield Act of 2004. ${ }^{2}$ That statute was designed "to provide protections and countermeasures against chemical, radiological, or nuclear agents that may be used in a terrorist attack against the United States.”3 The most prominent parts of that legislation were its procurement provisions designed to address the key significant impediment to biodefense vaccine production - lack of a significant market. ${ }^{4}$ These provisions encourage the development of effective vaccine countermeasures by establishing the Special Reserve Fund of $\$ 5.6$ billion to be spent over ten years to purchase for the nation's Strategic National Stockpile (SNS) the "next generation of countermeasures against" a broad array of chemical, biological, radiological, and nuclear [CBRN] agents, all of which were seen by Congress as weapons that could be deployed against the United States in the War on Terror. ${ }^{5}$ Due to the substantial expense and risk of bringing a vaccine to market, along with the infrequency with which these diseases occur naturally, pharmaceutical manufacturers have little to no incentive to invest without BioShield funds. ${ }^{6}$

\footnotetext{
${ }^{1}$ Law School Professor, University of Maryland School of Law; Director, University of Maryland Center for Health and Homeland Security. A.B., Lafayette College; J.D., University of Pennsylvania.

${ }^{2}$ Project BioShield Act, Pub. L. 108-276, 118 Stat. 835 (2004).

${ }^{3}$ Project BioShield Act, Pub. L. 108-276, 118 Stat. 835, 835 (2004).

${ }^{4}$ Frank GotTROn, Project BIoShIELd 1 (Cong. Research Serv., CRS Report for Congress Order Code RS 21507, Dec. 27, 2004), available at http://www.fas.org/sgp/crs/terror/RS21507.pdf (last visited Nov. 30, 2005) [hereinafter GOTTRON].

${ }^{5}$ United States Department of Health \& Human Services [hereinafter HHS], HHS Fact Sheet - Project BioShield, July 21, 2004, http://www.hhs.gov/news/press/2004pres/20040721b.html (last visited Nov. 30, 2005).

${ }^{6}$ Hearing Before H. Select Comm. on Homeland Security, 108th Cong. (May 15, 2003) (statement of Alan Pemberton, Pharmaceutical Research and Manufacturers of America), available at
} 
In order for a portion of the BioShield Special Reserve Fund to be released for the purchase of a countermeasure for SNS, a series of actions must occur. ${ }^{7}$ The first action, however, (and the one on which all later actions are based) is that "the Homeland Security [DHS] Secretary, in consultation with the [Health and Human Services (HHS)] Secretary and the heads of other agencies as appropriate," must make a "determination" of "current and emerging threats of CBRN agents" that "present a material threat against the United States ..."8 Once that "material threat assessment" is made, various government agencies, up to and including the President, through a series of decisions, then determine whether promising countermeasures may be purchased with the Special Reserve Fund to address those identified threats. ${ }^{9}$

The BioShield Act established no procedure for DHS to employ in supervising the making of the material threat determinations. Despite what was an obvious Congressional invitation to determine summarily what are widely recognized to be dozens of CBRN threats to the United States, DHS has employed an opaque, bureaucratized, lengthy process for determining material threats. Since the statute's passage, DHS has made only the following four material threat determinations: anthrax, smallpox, botulinum toxin, and radiological/nuclear devices. ${ }^{10}$ At a July 12, 2005 Congressional hearing, DHS officials promised that by the close of the 2005 fiscal year (September 30, 2005), additional material threat determinations would be

http://www.globalsecurity.org/security/library/congress/2003_h/5-15-03_pharmaceutical.pdf (last visited Nov. 30, 2005); GOTTRON, supra note 4, at 1-2.

${ }^{7}$ Project BioShield Act, Pub. L. 108-276, §3(a)(2), 118 Stat. 835, 843-52 (2004); HHS, Procurement Items BioShield Funds, Mar. 23, 2005, http://www.hhs.gov/ophep/bioshield/bioshieldfunds.html (last visited Nov. 30, 2005) (hereinafter HHS Procurement).

${ }^{8}$ Project BioShield Act, Pub. L. 108-276, § 3(a)(2), 118 Stat. 835, 844 (2004).

${ }^{9}$ Project BioShield Act, Pub. L. 108-276, § 3(a)(2), 118 Stat. 835, 843-48 (2004); HHS Procurement, supra note 7.

${ }^{10}$ See, e.g., Hearing Before the H. Subcomm. on National Security, Emerging Threats, and International Relations of the H. Comm. on Government Reform, 109th Cong. 4 (June 14, 2005) (statement of Dr. John Vitko, Jr., Director, Biological Countermeasures Portfolio, Science and Technology Directorate, Department of Homeland security), available at http://reform.house.gov/UploadedFiles/ST.Govt\%20Ref.Vitko.06-14-05.pdf (last visited Dec. 20, 2005). 
made concerning plague, tularemia, and viral hemorrhagic fevers. ${ }^{11}$ As of December 20, 2005, well into the 2006 government fiscal year, however, no further material threat determinations have been made beyond the original four.

Because there have only been material threat determinations pertaining to four CBRN agents, BioShield's Special Reserve Fund can only be used for countermeasures directed to those agents. Accordingly, only three contracts have been let using the Special Reserve Fund since BioShield's enactment in July 2004 - two directed to the purchase of anthrax vaccines and one for the delivery of pediatric doses of liquid potassium iodide (to be used in the event of the release of radioactive iodine). ${ }^{12}$ Even if a promising countermeasure were to meet the other requirements for purchase under the statute, it would be ineligible for procurement if there were no corresponding finding that the agent to which it was directed was a "material threat."13

DHS' lassitude in supervising the making of material threat findings is mystifying. The legislative history of the statute is replete with references to a myriad of agents, beyond the four agents now identified, posing a substantial threat to the United States. Moreover, the Center for Disease Control and Prevention (CDC) has a long established and widely recognized hierarchy of highly damaging biological agents that are likely to be deployed by terrorists against the United States. CDC's Category A agents, ranked as the most dangerous to the United States,

\footnotetext{
${ }^{11} I d$.

${ }^{12}$ HHS, Project BioShield Related Procurement Activities, http://www.hhs.gov/ophep/bioshield/PBPrcrtPrjct.htm (last visited Nov. 30, 2005).

${ }^{13}$ Indeed, testifying before the House Committee on Homeland Security on July 12, 2005, representatives from several pharmaceutical and biotechnology companies expressed frustration that, because the appropriate material threat determinations had not been made, no market using the Special Reserve Fund exists for what they viewed as promising CBRN countermeasures. See, e.g., Project BioShield: Linking Bioterrorism Threats and Countermeasure Procurement to Enhance Terrorism Preparedness: Hearing Before the Subcomm. on Emergency Preparedness, Science, and Technology of the H. Comm. on Homeland Security, 109th Cong. (July 12, 2005) (statements of David P. Wright, President and CEO, PharmAthene, Inc.; James A. Joyce, Chariman, CEO, and Founder, Aethlon Medical, Inc.; Nancy Wysenski, President, EMD Pharmaceuticals, Inc.; Marcus Eugene Carr, Jr., Executive Director for Clinical Research - Hemostasis, Novo Nordisk), available at http://homeland.house.gov/files/TestimonyWright.pdf; http://homeland.house.gov/files/TestimonyJoyce.pdf; http://homeland.house.gov/files/TestimonyWysenski.pdf; http://homeland.house.gov/files/TestimonyCarr.pdf (last visited Dec. 20, 2005);
} 
include anthrax, botulism, plague, smallpox, tularemia, and viral hemorrhagic fevers (including Ebola and Marburg). Only three of those agents have as yet been identified under the BioShield bureaucracy as posing a material threat. When one looks at the Category B and C agents identified by the CDC, there are over twenty more agents which ultimately will need to be addressed with medical countermeasures. ${ }^{14}$ At the rate the "material threat" findings have been made to date, it could be years before BioShield procurement funds can be used to purchase products designed to counter the as yet undesignated agents.

Leaving the CDC's findings to the side, scholarship on terrorist threats abound with long standing and well recognized findings about a significant number of CBRN agents likely to be deployed against the United States. Jessica Stern, for example, in her 1999 classic, The Ultimate $\underline{\text { Terrorists, }}$, lists two dozen chemical agents that have been historically deployed by terrorists going all the way back to World War I. ${ }^{15}$ Not one of these chemical agents has been certified under DHS' leadership. Nor has DHS even committed to making such designations in the future. Quite ironically, under other provisions of the BioShield statute concerning HHS funding for research (which does not require a "material threat" finding), grants have been made for the development of countermeasures relating to tularemia, Ebola, and plague. ${ }^{16}$ Yet, none of these agents has yet been designated as a material threat. If HHS has already commenced funding for research in this area, one would assume that there is substantial evidence available to DHS demonstrating that these agents should be so designated.

Substantial National Institutes of Health (NIH) funding outside of the BioShield appropriations is being committed to the development of medical countermeasures for agents not

\footnotetext{
${ }^{14}$ CDC, Bioterrorism Agents/Diseases (Nov. 19, 2004), http://www.bt.cdc.gov/agent/agentlist-category.asp (last visited Nov. 30, 2005).

15 JESSiCA STERN, THE UltimAte TERrorists 24-25 (1999).

${ }^{16}$ Press Release, HHS, NIH News, NIAID Awards First \$27 Million Using New BioShield Authorities (May 9, 2005), http://www.nih.gov/news/pr/may2005/niaid-09.htm (last visited Nov. 30, 2005).
} 
yet declared to be "material threats." For example, the Mid-Atlantic Regional Center of Excellence for Biodefense and Emerging Infectious Diseases is researching countermeasures for tularemia as part of a five-year grant from the National Institute of Allergy and Infectious Diseases, which is supported by funding wholly apart from monies appropriated under the BioShield statute. ${ }^{17}$ Simultaneously, plague vaccine research is being performed by the University of Maryland School of Medicine's Center for Vaccine Development that is funded by an NIH U19 grant, ${ }^{18}$ again a project being done wholly apart from the BioShield Act.

The BioShield Act is an impressive starting point for the creation of a vibrant biodefense vaccine industry. It has many problems that must be corrected both administratively and legislatively, however. ${ }^{19}$ Certainly, foremost among those problems is DHS' bureaucratic quagmire in identifying CBRN agents posing a material threat to the United States (thereby delaying the use of procurement efforts for well recognized CBRN dangers to this country).

No legislative fix is needed. What is required is aggressive Congressional prodding to have DHS abandon its unnecessary administrative morass. It requires directing the agency to follow the well worn path already trodden through scholarship and the work of the CDC to list quickly the full panoply of CBRN agents as material threats. Such an expedited effort would be an encouragement to both researchers and the vaccine industry that a broad array of efforts might be funded over the next decade by the BioShield Special Reserve Fund.

\footnotetext{
${ }^{17}$ Virginia Bioinformatics Institute, Mid-Atlantic Regional Center of Excellence, https://www.vbi.vt.edu/article/view/426 (last visited Nov. 30, 2005).

${ }^{18}$ Center for Vaccine Development, Nataro Lab, University of Maryland School of Medicine, http://medschool.umaryland.edu/cvd/natarolab/natarolab.html (last visited Nov. 30, 2005).

${ }^{19}$ For a complete description of the problems with implementing the BioShield statute, see Crossing the Valley of Death: Bringing Promising Medical Countermeasures to BioShield: Hearing Before the S. Subcomm. on Health of the S. Comm. on Health, Education, Labor, and Pensions, 109th Cong. (June 9, 2005) (statement of Dr. Phillip Russell, Major general, Retired, U.S. Army), available at $\mathrm{http}: / /$ help.senate.gov/testimony/t313_tes.html (last visited Nov. 30, 2005).
} 
Finally, it should be noted that the legislation introduced in April 2005 as a corrective to the BioShield Act (S. 975, or the Project BioShield II Act of 2005) places the major procurement responsibility principally in the hands of DHS, reducing substantially the role of HHS. ${ }^{20}$

Supposedly, this displacement is in reaction to industry supporters of BioShield II who view "HHS as having a contentious relationship with the biopharma industry." 21 However, given the difficulties DHS has had with effectively carrying out its single major mission under the existing legislation, Congress should think long and hard before it puts the entire biodefense vaccine apparatus under DHS.

\footnotetext{
${ }^{20}$ ARnOld \& PORTER, LLP, Client AdVISORY: "BiOShIEld II” BILl WOUld EXPAND INCENTIVES TO DEVELOP BIODEFENSE COUNTERMEASURES 1 (May 2005), http://www.arnoldporter.com/pubs/files/A\&PAdvisoryBioshieldII(0505).pdf (last visited Nov. 30, 2005).

${ }^{21} I d$. at 2.
} 